\title{
Methanobacterium beijingense sp. nov., a novel methanogen isolated from anaerobic digesters
}

Correspondence

Xiuzhu Dong

dongxz@sun.im.ac.cn

\author{
Kai Ma, Xiaoli Liu and Xiuzhu Dong \\ State Key Laboratory of Microbial Resources, Institute of Microbiology, Chinese Academy of \\ Sciences, Beijing 100080, PR China
}

\begin{abstract}
Two methanogenic strains, $8-2^{\top}$ and 4-1, with rod-shaped $(0 \cdot 4-0.5 \times 3-5 \mu \mathrm{m})$, non-motile cells, sometimes observed in chains, were isolated from two anaerobic digesters in Beijing, China. The two strains used $\mathrm{H}_{2} / \mathrm{CO}_{2}$ and formate for growth and produced methane.

The temperature range for growth was $25-50{ }^{\circ} \mathrm{C}$, with fastest growth at $37^{\circ} \mathrm{C}$. The $\mathrm{pH}$ ranges for growth and methane production were $6 \cdot 5-8 \cdot 0$ for strain $8-2^{\top}$ and $6 \cdot 8-8 \cdot 6$ for strain $4-1$, with the fastest growth at $\mathrm{pH} 7 \cdot 2$ for strain $8-2^{\top}$ and $\mathrm{pH} 7 \cdot 5-7 \cdot 7$ for strain $4-1$. The $\mathrm{G}+\mathrm{C}$ content of genomic DNA for strain $8-2^{\top}$ was $38.9 \mathrm{~mol} \%$. The similarity levels of the $16 \mathrm{~S}$ rRNA sequence of strain $8-2^{\top}$ with other species of the genus Methanobacterium ranged from $93 \cdot 8$ to $96.0 \%$. Based on the phylogenetic analysis and phenotypic characteristics, the novel species Methanobacterium beijingense sp. nov. is proposed, with the type strain $8-2^{\top}$ (=DSM $15999^{\top}=$ CGMCC $1.5011^{\top}$ ).
\end{abstract}

Methanogens share primarily two common physiological characteristics, namely growing strictly anaerobically and producing methane as the exclusive final product of energy metabolism (Garcia, 1990). In contrast to their significantly similar energy metabolism, methanogens inhabit extremely diverse environments, including freshwater and marine sediments, the digestive and intestinal tracts of animals and anaerobic waste digesters (Jones et al., 1987). So far, 28 genera of methanogens have been described. The majority of rod-shaped methanogens are affiliated to the order Methanobacteriales, which consists of three mesophilic genera (Methanobacterium, Methanobrevibacter and Methanosphaera) and two thermophilic or hyperthermophilic genera (Methanothermobacter and Methanothermus). All methanogens grow on a $\mathrm{H}_{2} / \mathrm{CO}_{2}$ gas mixture; in addition, many of them utilize formate and some grow on a few other simple alcohols. The anaerobic digester is a compatible surrounding for the growth of mesophilic methanogens and Methanobacterium strains constitute the main microbial flora, which play an important role in the anaerobic degradation of organic compounds as the terminal metabolic groups (Hobson \& Shaw, 1973).

When surveying the microbial communities of two mesophilic methane-producing up-flow anaerobic sludge blanket

Published online ahead of print on 27 August 2004 as DOI 10.1099/ ijs.0.63254-0.

Abbreviation: UASB, upflow anaerobic sludge blanket.

The GenBank/EMBL/DDBJ accession numbers for the 16S rRNA gene sequences of strains $8-2^{\top}$ and $4-1$ are AY350742 and AY552778.
(UASB) reactors, we isolated 11 strains of rod-shaped methanogens that produced methane from $\mathrm{H}_{2} / \mathrm{CO}_{2}$. Two strains from two different reactors showed high similarity of $16 \mathrm{~S}$ rRNA gene sequences and phenotypic characters; however, they were distantly related to all existing species of the genus Methanobacterium. Based on phylogenetic and phenotypic data, a novel species of Methanobacterium is proposed.

Methanobacterium formicicum DSM $1535^{\mathrm{T}}$, Methanobacterium congolense DSM $7095^{\mathrm{T}}$ and Methanobacterium oryzae DSM $11106^{\mathrm{T}}$ were purchased from the DSMZ (Braunschweig, Germany). Strains $8-2^{\mathrm{T}}$ and $4-1$ were isolated respectively from the granular sludge of a mesophilic UASB reactor treating beer-manufacture wastewater in Tsinghua University and one treating wastewater of bean-curd manufacture in Beijing.

The pre-reduced basal medium was prepared as described previously (Zehnder \& Wuhermann, 1977), but omitting rumen fluid and titanium solution. The medium was dispensed in screw-capped tubes sealed with butyl rubber stoppers and the gas phase was $\mathrm{H}_{2} / \mathrm{CO}_{2}\left(80: 20,1 \cdot 01 \times 10^{5} \mathrm{~Pa}\right)$ for routine cultivation unless indicated. All inoculations and transfers were done with syringes and needles and all cultures were incubated at $37^{\circ} \mathrm{C}$ in the dark. Substrate utilization was tested by measuring methane production from basal medium with the addition of each tested compound, and $\mathrm{N}_{2} / \mathrm{CO}_{2}\left(80: 20,1 \cdot 01 \times 10^{5} \mathrm{~Pa}\right)$ was used instead of $\mathrm{H}_{2} / \mathrm{CO}_{2}$ as the gas phase. Requirement for growth factors was determined by measuring growth in the $\mathrm{H}_{2} / \mathrm{CO}_{2}$ medium omitting one of the components in each test, which included vitamins, yeast extract, peptone, acetate, etc. The $\mathrm{pH}$ range 
for growth was estimated by cultivating the strains in the $\mathrm{H}_{2} / \mathrm{CO}_{2}$ medium with various $\mathrm{pH}$ values adjusted with $10 \%$ (w/v) $\mathrm{NaOH}$ or $\mathrm{HCl}$. The growth temperature range was measured by cultivating the strains in a water bath with a temperature controller. To determine $\mathrm{NaCl}$ tolerance, 0-1000 $\mathrm{mM} \mathrm{NaCl}$ was added to the $\mathrm{H}_{2} / \mathrm{CO}_{2}$ medium. The fastest growth was determined by measuring methane production after 6 days cultivation. Specific growth rates were calculated from the linear part of methane production curves determined from the amount of methane at $24 \mathrm{~h}$ intervals according to the method of Lai et al. (2000). Methane production was measured by gas chromatograph GC-14B (Shimadzu).

Hungate anaerobic techniques were used for isolation and culture of the strains (Hungate, 1969). During enrichment, $0.5 \mathrm{~g}$ vancomycin $\mathrm{l}^{-1}$ (final concentration) (Kotelnikova et al., 1998) was added to the $\mathrm{H}_{2} / \mathrm{CO}_{2}$ medium to inhibit bacterial growth. The enrichments were serially diluted and single colonies were obtained by the Hungate roll-tube method after cultivation at $37^{\circ} \mathrm{C}$ for 14 days. Colonies that produced fluorescence under UV light at a wavelength of $420 \mathrm{~nm}$ (model 2071 Max. Watts 100; American Optical) were picked for further purification. The purity of cultures was examined periodically by monitoring the cell morphology, under the normal bright-field microscope, and colonies, as well as the absence of growth in rich media like peptone/yeast extract/glucose (PYG) broth.

Exponential-phase cells of strain $8-2^{\mathrm{T}}$ were used for morphological examination under a transmission electron microscope (H-600A; Hitachi). Before observation, cells were coated with palladium/iridium alloy with a high vacuum evaporator (HUS-5GB; Hitachi). Ultrathin sections were stained with uranyl acetate and lead citrate according to Reynolds (1963). The motility of cells was observed by phase-contrast microscope (BH-2; Olympus).

Cells from an exponentially growing culture were used to check susceptibility to lysis by $1 \%$ SDS and distilled water as a hypotonic solution (Boone \& Whitman, 1988). Cell lysis was determined by microscopic observation of cell integrity.

Genomic DNA extraction and purification were performed according to Marmur (1961) and Jarrell et al. (1992). The $\mathrm{G}+\mathrm{C}$ content was determined using the thermal denaturation method (Marmur \& Doty, 1962; Owen \& Pitcher, 1985) using Escherichia coli $\mathrm{K}-12$ as the reference. DNA-DNA relatedness was determined from the initial reassociation rate at $61 \cdot 5-65 \cdot 5^{\circ} \mathrm{C}$ according to the method of Owen \& Pitcher (1985). Both assays were performed by using a UV800 spectrophotometer (Beckman).

The 16S rRNA gene was amplified using the genomic DNA mentioned above as the template as described previously (Furlong et al., 2002). Purified PCR products of $\sim 1400 \mathrm{bp}$ were cloned into $\mathrm{pUCm}-\mathrm{T}$ vector and sequenced by Bioasia Company. The similarities of the 16S rRNA gene sequences to all sequences in GenBank were determined using the
BLASTN algorithm. The best matching sequences were retrieved from the database and aligned and similarity analysis was performed by CLUSTAL X (Thompson et al., 1994). The phylogenetic tree was constructed by using MEGA 2.1 software (Sudhir et al., 2001).

Soluble cell protein was extracted from the sonicated cell pellet of $50 \mathrm{ml}$ exponential cultures. The protein profile was determined by running an SDS-PAGE gel and visualized by silver staining.

Cells of the two strains were rod-shaped, $0 \cdot 4-0 \cdot 5 \times 3-5 \mu \mathrm{m}$ (Fig. 1), stained Gram-negative and were non-motile. The cells resisted disruption by $1 \%$ SDS (w/v) or hypotonic solution. Colonies of strains $8-2^{\mathrm{T}}$ and $4-1$ were greyishwhite, opaque and rounded with entire edges, and the diameter reached $0 \cdot 5-1 \cdot 0 \mathrm{~mm}$ after $2-3$ weeks cultivation at $37^{\circ} \mathrm{C}$ on $\mathrm{H}_{2} / \mathrm{CO}_{2}$ medium. The colonies produced bright fluorescence under UV light at $420 \mathrm{~nm}$. The two strains grew strictly anaerobically and growth was inhibited completely in the presence of air. $\mathrm{H}_{2} / \mathrm{CO}_{2}$ and formate supported growth and methane production. Acetate, methanol, ethanol, trimethylamine, isobutanol and isopropanol (each at $10 \mathrm{mM}$ ) were not used; however, $0.025 \%$ acetate $(\mathrm{w} / \mathrm{v})$ could stimulate growth of strain $8-2^{\mathrm{T}}$. Strains $8-2^{\mathrm{T}}$ and $4-1$ grew well without peptone and vitamins, whereas yeast

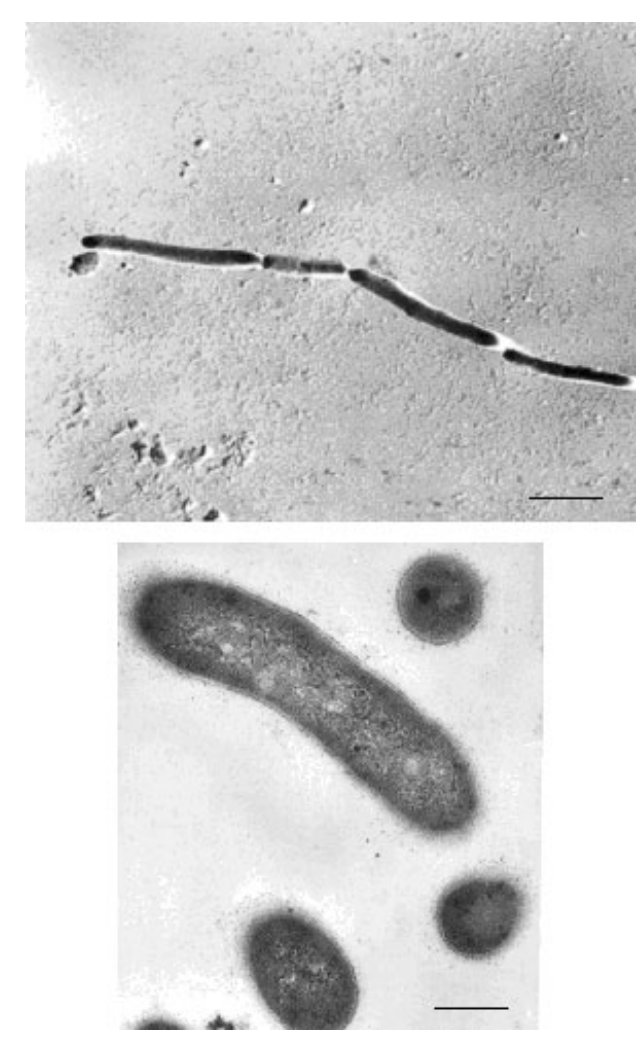

Fig. 1. Electron micrographs of cells of strain $8-2^{\top}$. (top) Transmission electron micrograph; bar, $1 \mu \mathrm{m}$. (bottom) Ultrathin section micrograph; bar, $0.2 \mu \mathrm{m}$. 


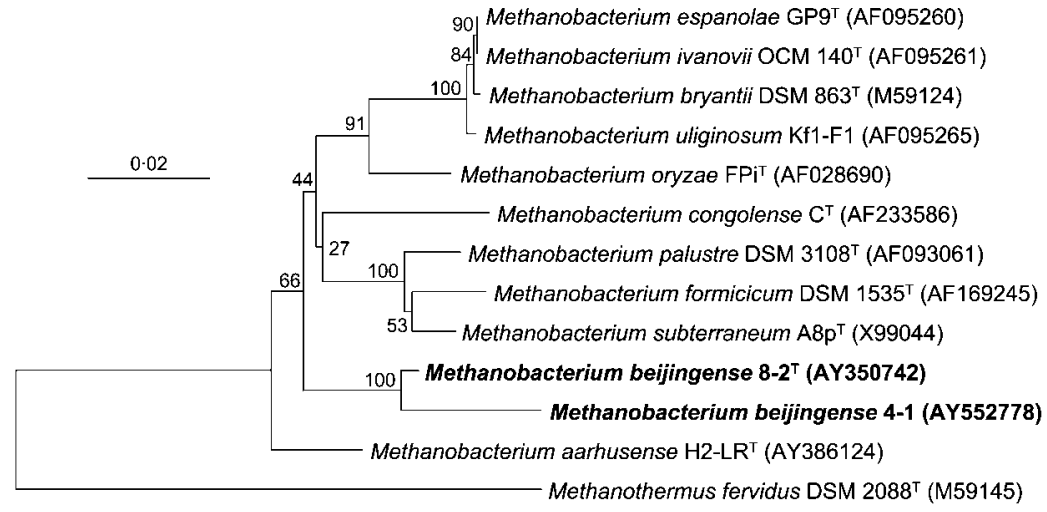

Fig. 2. Phylogenetic tree showing the position of strain $8-2^{\top}$ amongst other species of the genus Methanobacterium. Based on a consensus length of $1378 \mathrm{bp}$ of $16 \mathrm{~S}$ rRNA gene sequences, the tree was constructed by the neighbour-joining method and rooted with Methanothermus fervidus DSM $2088^{\top}$. The topology of the tree was estimated by bootstraps based on 1000 replications. Numbers at branch points are percentages supported by bootstrap evaluation. Numbers in parentheses are GenBank accession numbers. Bar, $2 \%$ sequence divergence. extract $(0 \cdot 1-2 \% \mathrm{w} / \mathrm{v})$ was indispensable. Growth of strains $8-2^{\mathrm{T}}$ and $4-1$ was observed in the temperature range $25-50{ }^{\circ} \mathrm{C}$, with fastest growth at $37^{\circ} \mathrm{C}$. The $\mathrm{pH}$ range for growth was $6 \cdot 5-8 \cdot 0$ for strain $8-2^{\mathrm{T}}$ and $6 \cdot 8-8 \cdot 6$ for strain 4-1 and the optimum $\mathrm{pH}$ for growth was $7 \cdot 2$ for strain $8-2^{\mathrm{T}}$ and $7 \cdot 5-7 \cdot 7$ for strain $4-1$. The specific growth rate of strain $8-2^{\mathrm{T}}$ was $0 \cdot 049 \mathrm{~h}^{-1}$ when grown in the $\mathrm{H}_{2} / \mathrm{CO}_{2}$ medium at $37^{\circ} \mathrm{C}$ and $0 \cdot 030,0 \cdot 023$ and $0 \cdot 021 \mathrm{~h}^{-1}$ in the absence of acetate, yeast extract and both, respectively. The $\mathrm{G}+\mathrm{C}$ content of the genomic DNA of strain $8-2^{\mathrm{T}}$ was $38 \cdot 9 \mathrm{~mol} \%$.

Phylogenetic analysis (Fig. 2) showed 98.2\% 16S rRNA gene sequence similarity between strains $8-2^{\mathrm{T}}$ and $4-1$; however, the similarity between $8-2^{\mathrm{T}}$ and other species of Methanobacterium ranged from 93.8 to $96 \%$, indicating that strain $8-2^{\mathrm{T}}$ could represent a novel species of this genus.

DNA-DNA relatedness values between strain $8-2^{\mathrm{T}}$ and its phylogenetic relatives Methanobacterium oryzae DSM $11106^{\mathrm{T}}$, Methanobacterium congolense DSM $7095^{\mathrm{T}}$ and Methanobacterium formicicum DSM $1535^{\mathrm{T}}$ were respectively $29 \cdot 5,25 \cdot 2$ and $7 \%$. SDS-PAGE profiles of whole-cell proteins (Fig. 3 ) of the three phylogenetic relatives also showed distinct protein patterns from strain $8-2^{\mathrm{T}}$.

All the phenotypic and phylogenetic characteristics of strains $8-2^{\mathrm{T}}$ and $4-1$ indicated their membership of the genus Methanobacterium; however, some phenotypic features distinguished them from others as follows: (i) they differed from Methanobacterium espanolae (Patel et al., 1990), Methanobacterium ivanovii (Belyaev et al., 1986), Methanobacterium uliginosum (König, 1984), Methanobacterium congolense (Cuzin et al., 2001), Methanobacterium bryantii (Zellner \& Winter, 1987) and Methanobacterium aarhusense (Shlimon et al., 2004) in their ability to produce methane from formate; (ii) they differed from Methanobacterium palustre in the latter's capacity to use secondary alcohols as sole carbon and energy sources (Zellner et al., 1989); (iii) they differed from Methanobacterium subterraneum and Methanobacterium alcaliphilum in their optimum $\mathrm{pH}$ for growth (Kotelnikova et al., 1998; Worakit et al., 1986); (iv) they differed from Methanobacterium oryzae in their higher growth temperature $\left(8^{\circ} \mathrm{C}\right.$ difference) (Joulian et al., 2000); and (v) they differed from Methanobacterium formicicum in colony size and shape (Bryant \& Boone, 1987). The characteristics that differentiate the novel strains from all other Methanobacterium species are shown in Table 1.

It had been proposed that strains with $\geqslant 3 \% 16 \mathrm{~S}$ rRNA gene sequence divergence could be regarded as different species (Stackebrandt \& Goebel, 1994). According to the minimal standards for new taxa of methanogens (Boone \& Whitman, 1987) and based on phylogenetic and phenotypic characters, a novel species of the genus Methanobacterium is proposed, Methanobacterium beijingense sp. nov.

\section{Description of Methanobacterium beijingense sp. nov.}

Methanobacterium beijingense (bei.jing.en'se. N.L. neut. adj. beijingense from Beijing, where the type strain was isolated).

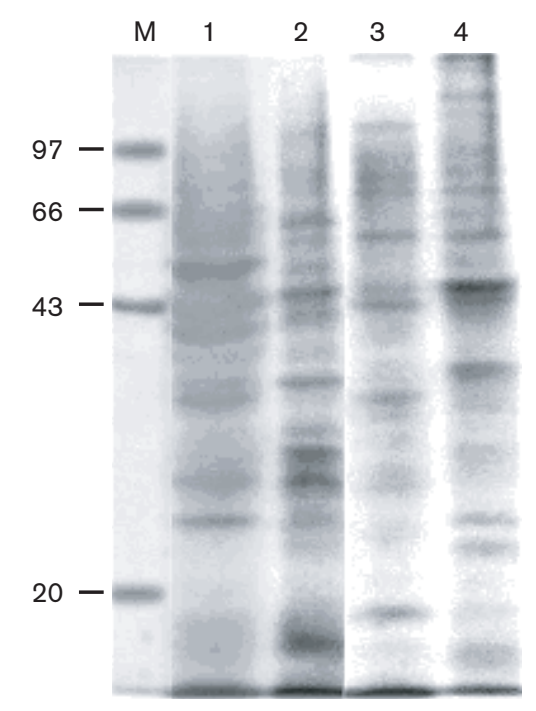

Fig. 3. Cell-protein SDS-PAGE profiles of strain $8-2^{\top}$ (lane 1), Methanobacterium oryzae DSM $11116^{\top}$ (2), Methanobacterium congolense DSM $7095^{\top}$ (3) and Methanobacterium formicicum DSM $1535^{\top}$ (4). Lane $M$, molecular mass markers (sizes in $\mathrm{kDa})$. 
Table 1. Differential characteristics between Methanobacterium beijingense sp. nov. and other species of Methanobacterium

Strains: 1, M. beijingense sp. nov. $8-2^{\mathrm{T}} ; 2$, M. beijingense sp. nov. 4-1; 3, M. formicicum DSM $1535^{\mathrm{T}}$ (data from Bryant \& Boone, 1987); 4, M. oryzae DSM 11106 ${ }^{\mathrm{T}}$ (Joulian et al., 2000); 5, M. congolense DSM $7095^{\mathrm{T}}$ (Cuzin et al., 2001); 6, M. palustre DSM 3108 ${ }^{\mathrm{T}}$ (Zellner \& Winter, 1987); 7, M. subterraneum DSM 11074 ${ }^{\mathrm{T}}$ (Kotelnikova et al., 1998); 8, M. alcaliphilum DSM $3387^{\mathrm{T}}$ (Worakit et al., 1986); 9, M. bryantii DSM 863 ${ }^{\mathrm{T}}$ (Boone, 1987); 10, M. espanolae OCM 178 ${ }^{\mathrm{T}}$ (Patel et al., 1990); 11, M. ivanovii DSM 2611 ${ }^{\mathrm{T}}$ (Belyaev et al., 1986); 12, M. uliginosum DSM $2956^{\mathrm{T}}$ (König, 1984); 13, M. aarhusense DSM $15219^{\mathrm{T}}$ (Shlimon et al., 2004). Abbreviations: ND, not determined; NG, alcohols are oxidized, but do not result in growth; iP, isopropanol; iB, isobutanol.

\begin{tabular}{|c|c|c|c|c|c|c|c|c|c|c|c|c|c|}
\hline Characteristic & 1 & 2 & 3 & 4 & 5 & 6 & 7 & 8 & 9 & 10 & 11 & 12 & 13 \\
\hline Source & $\begin{array}{c}\text { Anaerobic } \\
\text { digester }\end{array}$ & $\begin{array}{l}\text { Anaerobic } \\
\text { digester }\end{array}$ & $\begin{array}{c}\text { Sewage sludge } \\
\text { digester }\end{array}$ & Rice field & $\begin{array}{c}\text { Anaerobic } \\
\text { digester }\end{array}$ & Peat bog & $\begin{array}{l}\text { Deep granitic } \\
\text { groundwater }\end{array}$ & $\begin{array}{l}\text { Alkaline } \\
\text { lake }\end{array}$ & $\begin{array}{l}\text { Anaerobic } \\
\text { digester }\end{array}$ & Sludge & Rock core & $\begin{array}{l}\text { Marshy } \\
\text { soil }\end{array}$ & $\begin{array}{l}\text { Marine } \\
\text { sediment }\end{array}$ \\
\hline \multirow[t]{2}{*}{ Cell size } & $0 \cdot 4-0 \cdot 5$ & $0 \cdot 4-0 \cdot 5$ & $0 \cdot 4-0 \cdot 8$ & $0 \cdot 3-0 \cdot 4$ & $0 \cdot 4-0 \cdot 5$ & $0.5 \times 2.5$ & $0 \cdot 1-0 \cdot 15$ & $0 \cdot 5-0 \cdot 6$ & $0 \cdot 5-1 \cdot 0$ & $0 \cdot 8 \times$ & $0 \cdot 5-0 \cdot 8$ & $0 \cdot 2-0 \cdot 6 \times$ & $0 \cdot 7 \times$ \\
\hline & $\times 3-5$ & $\times 3-5$ & $\times 2-15$ & $\times 3-10$ & $\times 2-10$ & -5 & $\times 0 \cdot 6-1 \cdot 2$ & $\times 2-25$ & $\times 10-1 \cdot 5$ & $3-22$ & $\times 1-15$ & $1 \cdot 9-3 \cdot 8$ & $5-18$ \\
\hline Colony size (mm) & $0 \cdot 5-1 \cdot 0$ & $0 \cdot 5-1 \cdot 0$ & Up to 5 & $1-2$ & Up to 1 & ND & $1 \cdot 0-2 \cdot 0$ & $0 \cdot 2$ & $1-5$ & $0 \cdot 5-1 \cdot 0$ & $3-6$ & ND & ND \\
\hline \multicolumn{14}{|l|}{ Substrates used: } \\
\hline Formate & + & + & $+^{*}$ & + & $-^{*}$ & + & - & - & - & - & - & - & - \\
\hline $\mathrm{iP}, \mathrm{iB}$ & - & - & - & - & NG & + & - & ND & NG & NG & - & - & - \\
\hline \multicolumn{14}{|l|}{ Growth temperature $\left({ }^{\circ} \mathrm{C}\right)$ : } \\
\hline Range & $25-50$ & $25-50$ & ND & $20-42$ & $25-50$ & $20-45$ & $3 \cdot 6-45$ & ND & ND & $15-50$ & $15-55$ & $15-45$ & $5-48$ \\
\hline Optimum & 37 & 37 & $37-45$ & 40 & $37-42$ & $33-37$ & $20-40$ & 37 & $37-39$ & 35 & 45 & 40 & 45 \\
\hline \multicolumn{14}{|l|}{$\mathrm{pH}$ for growth: } \\
\hline Range & $6 \cdot 5-8 \cdot 0$ & $6 \cdot 8-8 \cdot 6$ & $6 \cdot 6-7 \cdot 8$ & $6 \cdot 0-8 \cdot 5$ & $5 \cdot 9-8 \cdot 2$ & ND & $6 \cdot 5-9 \cdot 2$ & $7 \cdot 0-9 \cdot 9$ & ND & $4 \cdot 6-7 \cdot 0$ & $6 \cdot 5-8 \cdot 5$ & $6 \cdot 0-8 \cdot 5$ & $5-9$ \\
\hline Optimum & $7 \cdot 2$ & $7 \cdot 5-7 \cdot 7$ & $\mathrm{ND}$ & $7 \cdot 0$ & $7 \cdot 2$ & $7 \cdot 0$ & $7 \cdot 8-8 \cdot 8$ & $8 \cdot 1-9 \cdot 1$ & $6 \cdot 9-7 \cdot 2$ & $5 \cdot 6-6 \cdot 2$ & $7 \cdot 0-7 \cdot 4$ & ND & $7 \cdot 5-8$ \\
\hline $\mathrm{NaCl}$ range $(\mathrm{M})$ & $0-0 \cdot 5$ & ND & ND & $0-0 \cdot 4$ & ND & $0-0 \cdot 3$ & $0 \cdot 2-1 \cdot 2$ & ND & ND & ND & ND & ND & ND \\
\hline $\mathrm{G}+\mathrm{C}$ content $(\mathrm{mol} \%) \dagger$ & $38 \cdot 9\left(T_{\mathrm{m}}\right)$ & ND & $41-42(\mathrm{Bd})$ & $31(\mathrm{Lc})$ & $\begin{array}{c}39 \cdot 5(\mathrm{Lc}) \\
44 \cdot 8\left(T_{\mathrm{m}}\right)^{*}\end{array}$ & $34\left(T_{\mathrm{m}}\right)$ & $54 \cdot 5\left(T_{\mathrm{m}}\right)$ & $57(\mathrm{Bd})$ & $\begin{array}{c}33-38 \\
(\mathrm{Bd})\end{array}$ & $34\left(T_{\mathrm{m}}\right)$ & $36 \cdot 6\left(T_{\mathrm{m}}\right)$ & $33 \cdot 8\left(T_{\mathrm{m}}\right)$ & $34 \cdot 9(\mathrm{Lc})$ \\
\hline
\end{tabular}

${ }^{\star}$ Checked in this study.

$\dagger$ Determined by buoyant density analysis (Bd), HPLC analysis (Lc) or melting point analysis $\left(T_{\mathrm{m}}\right)$. 
Cells are rod-shaped and non-motile and stain Gramnegative. Cells are resistant to lysis by $1 \%(\mathrm{w} / \mathrm{v})$ SDS and hypotonic solution. Colonies are greyish-white, opaque and rounded with entire edges and up to $1 \mathrm{~mm}$ in diameter. Methanogenic. Growth substrates include $\mathrm{H}_{2} / \mathrm{CO}_{2}$ and formate. No growth on acetate, methanol, ethanol, trimethylamine, isobutanol or isopropanol. Yeast extract is indispensable; however, peptone, vitamins and acetate are not required. Acetate stimulates growth. The temperature for growth ranges from 25 to $50^{\circ} \mathrm{C}$, with optimal growth at $37^{\circ} \mathrm{C}$. The $\mathrm{pH}$ value range for growth is $6 \cdot 5-8 \cdot 6$ and the optimum $\mathrm{pH}$ is $7 \cdot 2-7 \cdot 7$. The DNA base composition of the type strain is $38.9 \mathrm{~mol} \% \mathrm{G}+\mathrm{C}\left(T_{\mathrm{m}}\right)$.

The type strain, $8-2^{\mathrm{T}}\left(=\right.$ DSM $15999^{\mathrm{T}}=$ CGMCC $\left.1.5011^{\mathrm{T}}\right)$, was isolated from an anaerobic digester for the treatment of beer-manufacture wastewater.

\section{Acknowledgements}

This study was supported by the National Science Foundation of China under grants no. 30025001 and 30370001.

\section{References}

Belyaev, S. S., Obraztcova, A. Y., Laurinavichus, K. S. \& Bezrukova, L. V. (1986). Characteristics of rod-shaped methane-producing bacteria from oil pool and description of Methanobacterium ivanovii sp. nov. Microbiology (English translation of Mikrobiologiya) 55, 821-826.

Boone, D. R. (1987). Replacement of the type strain of Methanobacterium formicicum and reinstatement of Methanobacterium bryantii sp. nov. nom. rev. (ex Balch and Wolfe, 1981) with M.o.H. (DSM 863) as the type strain. Int J Syst Bacteriol 37, 172-173.

Boone, D. R. \& Whitman, W. B. (1988). Proposal of minimal standards for describing new taxa of methanogenic bacteria. Int J Syst Bacteriol 38, 212-219.

Bryant, M. P. \& Boone, D. R. (1987). Isolation and characterization of Methanobacterium formicicum MF. Int J Syst Bacteriol 37, 171.

Cuzin, N., Ouattara, A. S., Labat, M. \& Garcia, J.-L. (2001). Methanobacterium congolense sp. nov., from a methanogenic fermentation of cassava peel. Int J Syst Evol Microbiol 51, 489-493.

Furlong, M. A., Singleton, D. R., Coleman, D. C. \& Whitman, W. B. (2002). Molecular and culture-based analyses of prokaryotic communities from an agricultural soil and the burrows and casts of the earthworm Lumbricus rubellus. Appl Environ Microbiol 68, 1265-1279.

Garcia, J. L. (1990). Taxonomy and ecology of methanogens. FEMS Microbiol Rev 87, 297-308.

Hobson, P. N. \& Shaw, B. G. (1973). The bacterial population of piggery-waste anaerobic digesters. Water Res 8, 507-516.

Hungate, R. E. (1969). A roll tube method for the cultivation of strict anaerobes. Methods Microbiol 3B, 117-132.

Jarrell, K. F., Faguy, D., Hebert, A. M. \& Kalmokoff, M. L. (1992). A general method of isolating high molecular weight DNA from methanogenic archaea (archaebacteria). Can J Microbiol 38, $65-68$.
Jones, W. J., Nagle, D. P., Jr \& Whitman, W. B. (1987). Methanogens and the diversity of archaebacteria. Microbiol Rev 51, 135-177.

Joulian, C., Patel, B. K. C., Ollivier, B., Garcia, J.-L. \& Roger, P. A. (2000). Methanobacterium oryzae sp. nov., a novel methanogenic rod isolated from a Philippines ricefield. Int J Syst Evol Microbiol 50, 525-528.

König, H. (1984). Isolation and characterization of Methanobacterium uliginosum sp. nov. from a marshy soil. Can J Microbiol 30, 1477-1481.

Kotelnikova, S., Macario, A. J. L. \& Pedersen, K. (1998). Methanobacterium subterraneum sp. nov., a new alkaliphilic, eurythermic and halotolerant methanogen isolated from deep granitic groundwater. Int J Syst Bacteriol 48, 357-367.

Lai, M. C., Shu, C. M., Chen, S. C., Lai, L. J., Chiou, M.-S. \& Hua, J. J. (2000). Methanosarcina mazei strain O1M9704, methanogen with novel tubule isolated from estuarine environment. Curr Microbiol 41, 15-20.

Marmur, J. (1961). A procedure for the isolation of deoxyribonucleic acid from microorganisms. J Mol Biol 3, 208-218.

Marmur, J. \& Doty, P. (1962). Determination of the base composition of deoxyribonucleic acid from its thermal denaturation temperature. J Mol Biol 5, 109-118.

Owen, R. J. \& Pitcher, D. (1985). Current methods for estimating DNA base composition and levels of DNA-DNA hybridization. In Chemical Methods in Bacterial Systematics, pp. 67-93. Edited by M. Goodfellow \& D. E. Minnikin. London: Academic Press.

Patel, G. B., Sprott, G. D. \& Fein, J. E. (1990). Isolation and characterization of Methanobacterium espanolae sp. nov., a mesophilic, moderately acidiphilic methanogen. Int J Syst Bacteriol 40, 12-18.

Reynolds, E. (1963). The use of lead citrate at high $\mathrm{pH}$ as an electron opaque stain in electron microscopy. J Cell Biol 17, 208-212.

Shlimon, A. G., Friedrich, M. W., Niemann, H., Ramsing, N. B. \& Finster, K. (2004). Methanobacterium aarhusense sp. nov., a novel methanogen isolated from a marine sediment (Aarhus Bay, Denmark). Int J Syst Evol Microbiol 54, 759-763.

Stackebrandt, E. \& Goebel, B. M. (1994). Taxonomic note: a place for DNA-DNA reassociation and 16S rRNA sequence analysis in the present species definition in bacteriology. Int J Syst Bacteriol 44, 842-849.

Sudhir, K., Koichiro, T., Ingrid, B. J. \& Masatoshi, N. (2001). MEGA2: Molecular Evolutionary Genetics Analysis software. Arizona State University, Tempe, AZ, USA.

Thompson, J. D., Higgins, D. G. \& Gibson, T. J. (1994). CLUSTAL W: improving the sensitivity of progressive multiple sequence alignment through sequence weighting, position-specific gap penalties and weight matrix choice. Nucleic Acids Res 22, 4673-4680.

Worakit, S., Boone, D. R., Mah, R. A., Abdel-Samie, M.-E. \& El-Halwagi, M. M. (1986). Methanobacterium alcaliphilum sp. nov., an $\mathrm{H}_{2}$-utilizing methanogen that grows at high $\mathrm{pH}$ values. Int $J$ Syst Bacteriol 36, 380-382.

Zehnder, A. J. B. \& Wuhermann, K. (1977). Physiology of a Methanobacterium strain AZ. Arch Microbiol 111, 199-205.

Zellner, G. \& Winter, J. (1987). Secondary alcohols as hydrogen donors for $\mathrm{CO}_{2}$-reduction by methanogens. FEMS Microbiol Lett 44, 323-328.

Zellner, G., Bleicher, K., Braun, E., Kneifel, H., Tindall, B. J., Conway de Macario, E. \& Winter, J. (1989). Characterization of a new mesophilic secondary alcohol-utilizing methanogen, Methanobacterium palustre sp. nov. from a peat bog. Arch Microbiol 151, 1-9. 